\title{
Distribution of Oecomys catherinae Thomas, 1909 (Rodentia: Cricetidae) in northeastern Brazil with karyotypical and morphometrical notes
}

\author{
Paulo Henrique Asfora ${ }^{1,4}$, Alexandre Ramlo Torre Palma ${ }^{2}$, Diego Astúa ${ }^{3}$ \& Lena Geise ${ }^{1}$ \\ ${ }^{1}$ Departamento de Zoologia, Laboratório de Mastozoologia, Universidade do Estado do Rio de Janeiro - \\ UERJ, Rua São Francisco Xavier 524, CEP 20550-013, Maracanã, Rio de Janeiro, RJ, Brazil \\ ${ }^{2}$ Departamento de Sistemática e Ecologia, Universidade Federal da Paraíba - UFPB, \\ Castelo Branco, João Pessoa, PB, Brazil \\ ${ }^{3}$ Departamento de Zoologia, Laboratório de Mastozoologia, Universidade Federal de Pernambuco - UFPE, \\ Av. Prof. Moraes Rego s/n, CEP 50670-420, Cidade Universitária, Recife, PE, Brazil \\ ${ }^{4}$ Corresponding author e-mail: Paulo Henrique Asfora, E-mail: paulo.asfora@gmail.com
}

ASFORA P.H., PALMA A.R.T., ASTÚA D. \& GEISE L. Distribution of Oecomys catherinae Thomas, 1909 (Rodentia: Cricetidae) in northeastern Brazil with karyotypical and morphometrical notes. Biota Neotrop. 11(2): http://www.biotaneotropica.org.br/v11n2/en/abstract?inventory+bn00811022011

\begin{abstract}
The genus Oecomys Thomas, 1906 is currently composed of 16 species with unclear taxonomy and poorly known geographic limits. O. catherinae Thomas, 1909 is known to occur within the Brazilian Atlantic Forest from the states of Santa Catarina to Pernambuco (where the northernmost previously known specimen of Oecomys in the Atlantic forest was recorded), and along riverine forest into the Cerrado. To gain a greater understanding of its geographical and ecological distribution (mainly in Northeastern Brazil) and of its taxonomic characterization, we provide a short review of karyotypical and morphometrical data from specimens collected within the distribution range of the species. Specimens presented $2 n=60$ and AN varying between 62 and 64 . A table with external and cranial measurements of the analyzed specimens is provided. In this paper we also report the presence of $O$. catherinae in the semi-deciduous forests of the state of Paraíba, representing the northernmost records of the species in the Atlantic forest and thereby extending its known geographical limits.

Keywords: small mammals, new register, Sigmodontinae, cytogenetic, morphometrics.
\end{abstract}

ASFORA P.H., PALMA A.R.T., ASTÚA D. \& GEISE L. Distribuição de Oecomys catherinae Thomas, 1909 (Rodentia: Cricetidae) no nordeste do Brasil com notas morfométricas e cariotípicas. Biota Neotrop. 11(2): http://www.biotaneotropica.org.br/v11n2/pt/abstract?inventory+bn00811022011

Resumo: Oecomys Thomas, 1906 é um gênero atualmente composto por 16 espécies reconhecidas que apresentam taxonomia e distribuições geográficas ainda incertas. O. catherinae Thomas, 1906 é a espécie que ocorre ao longo da Floresta Atlântica brasileira dos estados de Santa Catarina a Pernambuco, onde se encontra o registro prévio mais ao norte para Oecomys na Floresta Atlântica, e ao longo de florestas de galeria no Cerrado. Pretendendo esclarecer aspectos relacionados à distribuição geográfica e ecológica de $O$. catherinae, com ênfase na região nordeste do Brasil, e auxiliar na sua caracterização taxonômica, fornecemos um breve resumo de dados morfométricos e cariotípicos de indivíduos coletados em diversos trabalhos ao longo da área de ocorrência da espécie. Os espécimens apresentaram $2 \mathrm{n}=60$ e NA variando entre 62 e 64 . Uma tabela de medidas corporais externas e cranianas dos indivíduos analisados é fornecida. Também registramos pela primeira vez a presença de O. catherinae nas florestas semi-deciduais do estado da Paraíba, sendo atualmente os registros mais ao norte da espécie na Floresta Atlântica, estendendo os limites geográficos conhecidos para a espécie.

Palavras-chave: pequenos mamíferos, novo registro, Sigmodontinae, citogenética, morfometria. 


\section{Introduction}

The genus Oecomys Thomas, 1906 is currently composed of 16 species that present an unclear taxonomy and geographic distribution (Musser \& Carleton 2005), 12 of which occur in Brazil: O. auyentepui Tate, 1939, O. bicolor (Tomes, 1860), O. catherinae Thomas, 1909, O. cleberi Locks, 1981, O. concolor (Wagner, 1845), O. marmorae (Thomas, 1906), O. paricola (Thomas, 1904), O. rex Thomas, 1910, O. roberti (Thomas, 1904), O. rutilus Anthony, 1921, O. superans Thomas, 1911 and O. trinitatis (J. A. Allen and Chapman, 1893) (see Bonvicino et al. 2008).

Hershkovitz (1960) considered all known Oecomys taxa as junior synonymous of two species, $O$. concolor (the largebodied species) or $O$. bicolor (the small-bodied species). Some papers then refer to Oecomys specimens recorded in the Brazilian Atlantic Forest and Cerrado as $O$. concolor or $O$. group concolor (Andrades-Miranda et al. 2001, Andrade \& Bonvicino 2003). Langguth et al. (2005) state that the specimens of Oecomys from the state of Pernambuco differ from $O$. concolor and refer to $O$. bahiensis (Hershkovitz, 1960) and could be co-specific with the animals sharing the same karyotype recorded further south in the Atlantic Forest, a diploid number (2n) of 60 and an autosomal number (AN) of 62, still called $O$. concolor in Langguth et al. (2005). Musser $\&$ Carleton (2005) treat $O$. bahiensis as a junior synonym of $O$. catherinae. So, for the purpose of this paper we considered the specimens of $O$. bahiensis and the specimens of Oecomys group concolor having a diploid number $(2 \mathrm{n})$ of 60 and an autosomal number (AN) of 62 as a synonym of $O$. catherinae

Cytogenetic analyses performed on several species of Oecomys suggest that this genus presents a karyotypical diversification with a diploid number ranging from 58 to 86 , yet some species within this genus present the same diploid number, being differentiated by their autosomal number (see Langguth et al. 2005), (Table 1, for a comprehensive review). Thus, karyotypes can be helpful in revealing the genetic diversity in the genus (Langguth et al. 2005).

According to Musser \& Carleton (2005), O. catherinae occurs in the Brazilian Atlantic Forest, from the states of Santa Catarina to Bahia and along riverine forest into the Cerrado and Caatinga regions, with poorly documented limits. Bonvicino et al. (2008) state that $O$. catherinae occurs from the states of Santa Catarina to Paraíba, citing Costa et al. (2004) - a paper not listed in their references section. In fact, Bonvicino et al. (2008) were referring to Costa et al. (2008), which states that $O$. catherinae occurs from the states of Santa Catarina to Bahia, and there are no records of the species in Paraíba (C.R. Bonvicino, personal communication). No other reference to the occurrence of $O$. catherinae in Paraíba state was found in the literature or in the collections of the Museu Nacional, Universidade Federal do Rio de Janeiro (MN), Museu de Zoologia da USP (MZUSP), Universidade Federal de Pernambuco (UFPE) or the Universidade Federal da Paraíba (UFPB) nor in any collection integrating the Species Link (http://www.splink.org.br) or MaNIS network (http://manisnet.org).

Therefore, the northernmost previously known recorded specimen of Oecomys in the Atlantic Forest was collected at Camaragibe, $6 \mathrm{~km}$ NE of São Lourenço da Mata $\left(08^{\circ} 00^{\prime} 00^{\prime \prime} \mathrm{S}\right.$ $35^{\circ} 03^{\prime} 00$ " O), in a remnant of the Atlantic Forest of Pernambuco (Oliveira \& Langguth 2004, Langguth et al. 2005).

We report here the presence of Oecomys catherinae (Figure 1) in two different localities in the state of Paraíba, Brazil, extending its known distribution in the northeastern Atlantic Forest further north and adding new ecological data about the species. We also present a short review of distributional, morphometrical, and karyological data, and give details on chromosomal variation in the autosomal number from individuals collected across the species distribution range.

\section{Material and Methods}

Trapping was carried out at two localities in the state of Paraíba. The first locality is Reserva Biológica Guaribas ( $06^{\circ} 44^{\prime} 59^{\prime}$ S, $41^{\circ} 07^{\prime} 11^{\prime}$ W), within the municipalities of Mamanguape and Rio Tinto. This reserve encompasses three noncontiguous areas: SEMA I (3016 ha), SEMA II (673 ha) and SEMA III (338 ha). The average annual rainfall is $1386 \mathrm{~mm} /$ year, with a dry season lasting from September to February (CPTEC/INPE 2009) and average annual temperature $25.5{ }^{\circ} \mathrm{C}$ (Hijmans et al. 2005). The vegetation of Reserva Biológica Guaribas is a mosaic of semi-deciduous forests located in valleys, and savannas with sandy soils on the tops of hills (" tabuleiros" vegetation) (Instituto..., 1993, Rodrigues and Silva et al. 2000). The second locality is Usina São João ( $07^{\circ} 06^{\prime} 56^{\prime}$ ' S, 35 $34^{\circ}$ ' 47' W), in the municipality of Cruz do Espírito Santo, with almost 700 ha of forest fragments. The average annual rainfall is $1294 \mathrm{~mm} /$ year (Instituto..., 2009) and average annual temperature is $25.0^{\circ} \mathrm{C}$ (Hijmans et al. 2005). The vegetation at Usina São João is also a mosaic of savanna and semi-deciduous forest (Instituto..., 1993), similar to Reserva Biológica Guaribas. Both sites are included in the Pernambuco Interior Forests ecoregion of the Brazilian Atlantic Forest (Olson et al. 2001).

Three trapping trips in Reserva Biológica Guaribas were carried out, in March 2008, September 2008 and May 2009, lasting 11, 8 and 5 consecutive nights, respectively, totaling 2,978 trap-nights. Two semi-deciduous forest sites and one savanna (Tabuleiro) site were sampled on each field trip. Two trapping trips were carried out in Usina São João, in January and October 2009, lasting 5 consecutive nights each, totaling 1,757 trap-nights. In this locality, one trap line was set in a semi-deciduous forest area (Figure 2), one in the Tabuleiro Forest (low forest on sandy soil), and a third at a Tabuleiro dense savanna site.

Live-traps (Sherman ${ }^{\odot}$ of three different sizes: height: 10/7.5/10 cm, width: 8/9/11 cm, depth: 30.5/23/38 $\mathrm{cm}$ and Tomahawk $^{\oplus}$ height: $15 \mathrm{~cm}$, width: $14 \mathrm{~cm}$, depth: $41 \mathrm{~cm}$ ) were

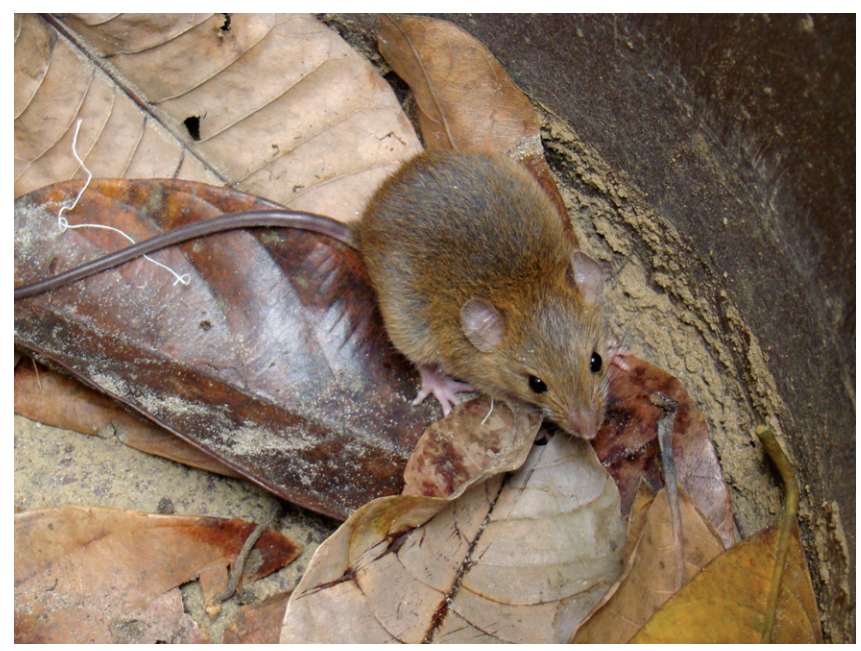

Figure 1. Individual of Oecomys catherinae (UFPE1890) trapped in Guaribas Biological Reserve. Juvenile male. Photo by Paulo Asfora.

Figura 1. Indivíduo de Oecomys catherinae (UFPE1890) capturado na Reserva Biológica Guaribas. Macho jovem. Foto: Paulo Asfora. 
distributed in points along linear transects formed by 30 trap stations, each $10 \mathrm{~m}$ apart from the next. At each station two traps were set; one on the ground and another fixed on tree branches about $2 \mathrm{~m}$ above the ground. Traps were baited with a mix of pineapple, banana, sardines, peanut butter and corn flower and were rebaited every other day.

All trapped animals were sexed, measured, weighed, and karyotyped in the field. Specimens were identified to species level by comparison of morphological characters (skin and skull) with descriptions in the literature (Langguth et al. 2005, Bonvicino et al. 2008) and karyological analysis (Andrade \& Bonvicino 2003, Langguth et al. 2005). Voucher specimens from the state of Paraíba were collected under IBAMA/ICMBio licenses \#11633-2 and \# 14734-1, and are currently housed at the Coleção de Mamíferos da Universidade Federal de Pernambuco.

Chromosomes in metaphases from our collected individuals were obtained with in vitro culture (culture of bone marrow grown in Dulbecco's MEM with 10\% fetal bovine serum and colchicine). Conventional coloration with Giemsa 5\% was used to count diploid (2n) and autosomal numbers (AN, excluding sexual chromosomes) and to observe variation in chromosome morphology. This analysis was carried out using an optic photomicroscope (Hund Wetzlar H500 LL HP100). We also summarize karyotipycal data of O. catherinae recorded across the species distribution found in the literature and from our unpublished data to present a review of the actual karyotypical data of the species.

For morphometric analysis we examined specimens of O. catherinae currently housed in MN, UFPE and UFPB as well as individuals collected by us in many localities (Appendix I) during this and previous trips. Following Geise et al. (2008), 20 cranial measurements were obtained with a digital caliper: condylo-incisive length (CIL), breadth of occipital condyles (BOC), length of diastema (LD), length of palatal bridge (LPB), length (LIF) and breadth (BIF) of incisive foramina, length of the maxillary molar row (LM), breadth of M1 (BM1), breadth between the first molars, including both teeth (M1M1), bullar length (BL), height of skull (HS), length of the rostrum (LR), rostrum width (RW), least interorbital length (LIB), internal orbital length (IOL), zygomatic breadth (ZB), breadth of the braincase (BB), breadth of the zygomatic plate (BZP), mandible height $(\mathrm{MH})$ and length (ML). Additionally, head-and-body length (HBL), tail length (TL), Hindfoot length (HF), Ear length (E) and body weight (W) were also analyzed. We performed descriptive statistic analyses of the external and cranial measurements of these specimens including a $t$-test to detect sexual dimorphism. Age classes were determined according to molar teeth wear (Cerqueira et al. 1989); only adult specimens were included in statistical analyses.

\section{Results and Discussion}

We collected 46 individuals of six marsupial species Caluromys philander Linnaeus, $1758(\mathrm{n}=2)$, Didelphis albiventris Lund, 1840 ( $\mathrm{n}=5$ ), Marmosa murina Linnaeus, $1758(\mathrm{n}=9)$ ), Micoureus demerarae Thomas, $1905(\mathrm{n}=10)$, Monodelphis domestica Wagner, $1842(\mathrm{~N}=2)$ and four rodent species - Akodon cursor Winge, 1887 ( $\mathrm{n}=12)$, Necromys lasiurus Lund, $1840(\mathrm{n}=1)$, Oecomys catherinae $(\mathrm{n}=4)$ and Oligoryzomys sp. $(\mathrm{n}=1)$.

Two specimens of $O$. catherinae were trapped in SEMA III, in Reserva Biológica Guaribas, a forest fragment that includes well-preserved late secondary semi-deciduous forest in a natural regeneration process of nearly 60 years (unpublished data). The first specimen was a young male (age class 2) trapped in March
2008 (museum number UFPE1890) and the second specimen was an adult male (museum number UFPE 1889, age class 3 ) trapped in September 2008. Another two specimens were trapped in October 2009 in Mata do Açude (semi-deciduous forest trap-line), in Usina São João (Figure 2); a male (museum number UFPE1896) and a female (museum number UFPE1897), both adults (age class 4). All were trapped in Sherman ${ }^{\circledR}$ traps set on tree branches at about $2 \mathrm{~m}$ off the ground.

These records show the occurrence of $O$. catherinae in the Atlantic Forest of the state of Paraíba, Brazil, representing the northernmost occurrence of the species and extending its distribution one degree of latitude and $122 \mathrm{~km}$ north of the previously known northernmost locality (Langguth et al. 2005). These records also represent an extension of the known ecological limits in northeastern Brazil beyond the coastal rainforests of the state of Pernambuco, in the Pernambuco Coastal Forests ecoregion, into the semi-deciduous forests of the state of Paraíba, part of the Pernambuco Interior Forests ecoregion (Olson et al. 2001) (see Table 1). These new records also place the distributional limits of $O$. catherinae very close to the northernmost limit of the Brazilian Atlantic Forest, just $110 \mathrm{~km}$ further north near the city of Natal (Instituto..., 1993). The records at Guaribas also lie very close $(9 \mathrm{~km})$ to the border between the Atlantic Forest and the semi-arid Caatinga shrublands (Instituto..., 1993) (Figure 3).

With these new records we suggest that the distribution limits of $O$. catherinae north from São Francisco river actually reach still further northward and further inland than previously recorded and may closely follow the limits of the Atlantic Forest. No O. catherinae specimens were recorded in the few studies including the "brejos úmidos" (Oliveira \& Langguth, 2004; Souza et al. 2004), which are forest enclaves on mesic ridges amidst semi-arid Caatinga.

In the Brazilian Atlantic Forest we found individuals identified as O. catherinae occurring from Joinville, in the state of Santa Catarina, the type locality (Cherem et al. 2004, Carleton et al. 2009), to the state of Espírito Santo (Pinto et al. 2009a, b). However, although Musser $\&$ Carleton (2005) and Costa et al. (2008) state that $O$. catherinae occurs from the states of Santa Catarina to Bahia, the only register of

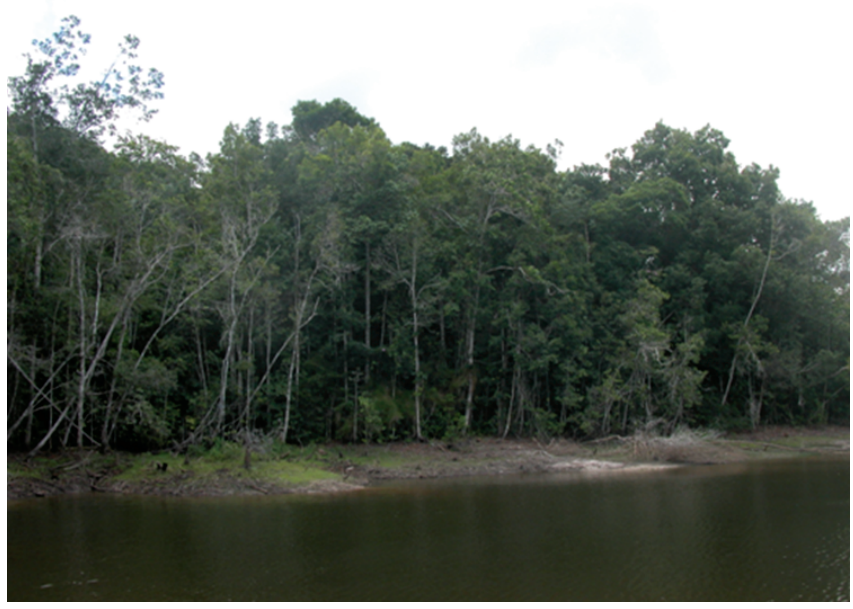

Figure 2. Photo of Mata do Açude in Usina São João representing the vegetation types where Oecomys catherinae was collected during field work. Photo by Alexandre Palma.

Figura 2. Foto da Mata do Açude, na Usina São João, representando o tipo de vegetação onde obtivemos capturas de Oecomys catherinae. Foto: Alexandre Palma. 
Asfora, P.H. et al.

Table 1. Characteristics of sites of occurrence of Oecomys catherinae at northern Atlantic Forest. $1=$ Altitude database ETOPO2 from NOAA \& NGDC (National... 2001); 2 = IBGE (Instituto... 1993); 3 = Hijmans et al. (2005); 4 = Langguth et al. (2005); 5 = Asfora \& Pontes (2009).

Tabela 1. Características dos locais de ocorrência de Oecomys catherinae na porção norte da Floresta Atlântica. 1 = Banco de dados de altitude ETOPO2 do NOAA \& NGDC (National... 2001); 2 = IBGE (Instituto... 1993); 3 = Hijmans et al. (2005); 4 = Langguth et al. (2005); $5=$ Asfora \& Pontes (2009).

\begin{tabular}{|c|c|c|c|c|c|}
\hline $\begin{array}{c}\text { Locality, } \\
\text { municipality }\end{array}$ & $\begin{array}{c}\text { Altitude }{ }^{1} \\
\text { (m) }\end{array}$ & Vegetation $^{2}$ & $\begin{array}{c}\text { Mean annual } \\
\text { temperature }^{3}\left({ }^{\circ} \mathrm{C}\right)\end{array}$ & $\begin{array}{c}\text { Rainfall }^{3} \\
(\mathrm{~mm} / \text { year})\end{array}$ & $\begin{array}{c}\text { Forest fragment } \\
\text { size (ha) }\end{array}$ \\
\hline REBIO Saltinho, Rio Formoso - $\mathrm{PE}^{4}$ & 26 & Dense rain forest & 23.8 & 1930 & 564 \\
\hline CIMNC, Paudalho - PE & 118 & Open rain forest & 24.4 & 1388 & 800 \\
\hline Usina São José, Igarassú- PE & 48 & Open rain forest & 24.8 & 1613 & 323 \\
\hline Rancho Mineiro, São Lourenço da Mata - $\mathrm{PE}^{4}$ & 47 & Open rain forest & 24.9 & 1473 & Unknown \\
\hline $\begin{array}{l}\text { RPPN Frei Caneca, } \\
\text { Jaqueira }- \text { PE }^{5}\end{array}$ & 640 & $\begin{array}{l}\text { Open rain forest with } \\
\text { semi-deciduous forest }\end{array}$ & 21.0 & 1113 & 500 \\
\hline $\begin{array}{l}\text { Usina São João, Cruz do } \\
\text { Espírito Santo - PB }\end{array}$ & 54 & $\begin{array}{l}\text { Semi-deciduous forest in } \\
\text { a savanna/forest mosaic }\end{array}$ & 25.0 & 1294 & 700 \\
\hline $\begin{array}{l}\text { REBIO Guaribas, } \\
\text { Mamanguape - PB }\end{array}$ & 20 & $\begin{array}{l}\text { Semi-deciduous forest in } \\
\text { a savanna/forest mosaic }\end{array}$ & 25.5 & 1337 & 338 \\
\hline $\begin{array}{l}\text { Usina Serra Grande, } \\
\text { Ibateguara }-\mathrm{AL}^{5}\end{array}$ & 390 & $\begin{array}{l}\text { Open rain forest with } \\
\text { semi-deciduous forest }\end{array}$ & 23.0 & 1225 & 3000 \\
\hline
\end{tabular}

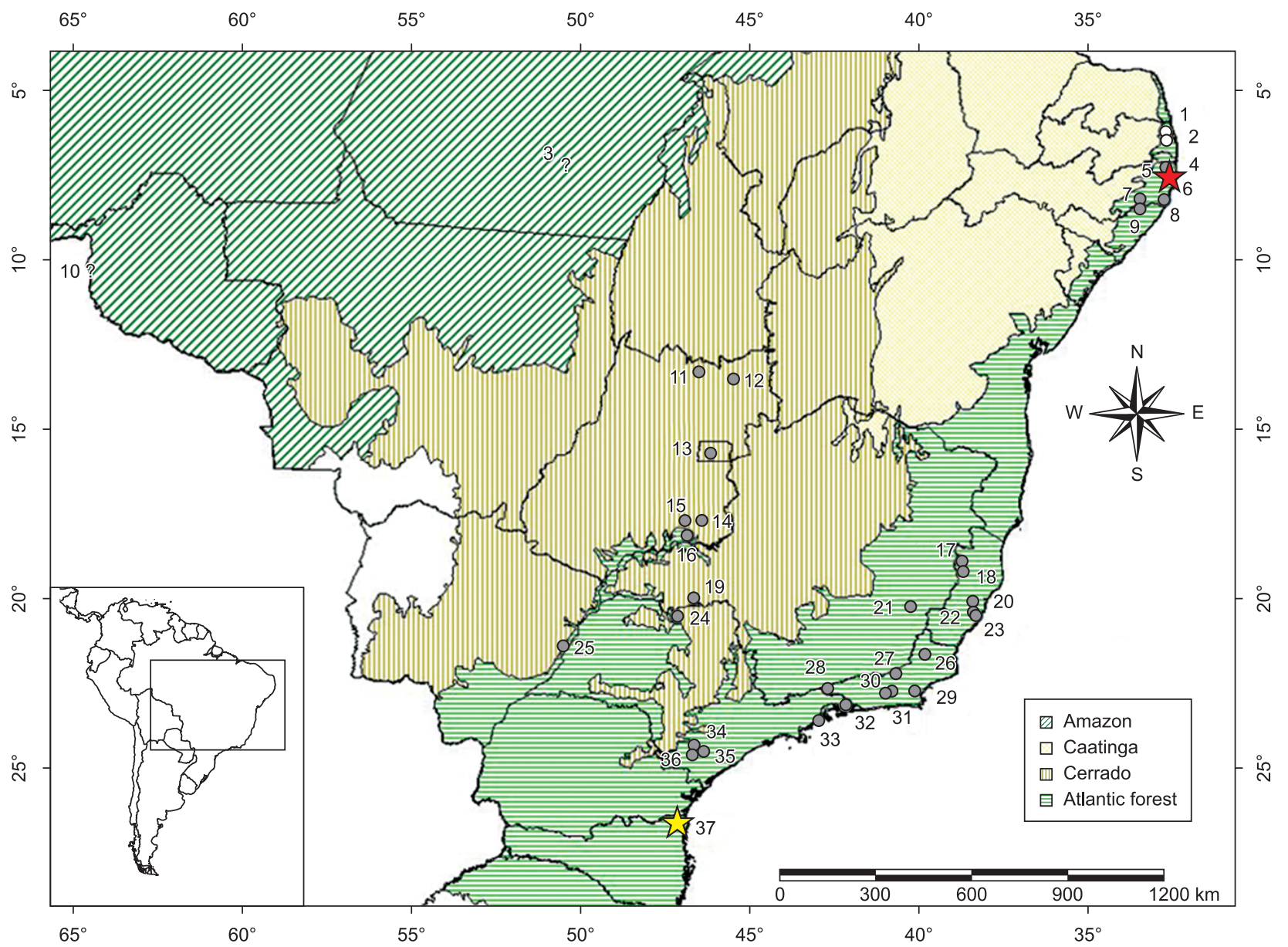

Figure 3. Distribution map of Oecomys catherinae showing the previous records (gray circles) and our new record sites (Reserva Biológica Guaribas, 1 , and Usina São João, 2, white circles). Type locality of $O$. catherinae (yellow star) and $O$. bahiensis (red star) are pointed on the map. ? represents possible occurrence based in published data, for more information see the text. Data from the examined Museums and from Percequillo et al. (2011), Carleton et al. (2009), Cáceres et al. (2008), Pinheiro \& Geise (2008), Lambert et al. (2006), Langguth et al. (2005), Cherem et al. (2004), Andrade \& Bonvicino (2003), Pinto et al. (2009a,b), AndradesMiranda et al. (2001), Asfora \& Pontes (2009), Vieira \& Palma (2005) and this paper. Localities numbers follow Appendix I.

Figura 3. Mapa de distribuição de Oecomys catherinae mostrando os registros anteriores conhecidos (círculos pretos) e as localidades dos novos registros (Reserva Biológica Guaribas, 1, e Usina São João, 2, círculos brancos). As localidades tipo de $O$. catherinae (estrela amarela) e $O$. bahiensis (estrela vermelha) estão indicados no mapa. ? indicam possíveis ocorrências baseadas na literature, consultar o texto para mais informações. Dados obtidos nas coleções visitadas e em Percequillo et al. (2011), Carleton et al. (2009), Cáceres et al. (2008), Pinheiro \& Geise (2008), Lambert et al. (2006), Langguth et al. (2005), Cherem et al. (2004), Andrade \& Bonvicino (2003), Pinto et al. (2009a,b), Andrades-Miranda et al. (2001), Asfora \& Pontes (2009), Vieira \& Palma (2005) e neste trabalho. Números das localidades seguem a tabela no Apêndice I. 
Oecomys collected in the state of Bahia was an individual identified as Oecomys sp. from Una (Pardini 2004). In the states of Pernambuco and Alagoas we found records of individuals identified as $O$. bahiensis (Langguth et al. 2005, Asfora \& Pontes 2009), synonymized as $O$. catherinae (Musser \& Carleton 2005). This apparently disjunct distribution in the Atlantic Forest could be an artifact of insufficient sampling effort in the northeastern region of Brazil, or alternately might suggest that $O$. bahiensis could be a valid species differing from $O$. catherinae.

We found several putative records of $O$. catherinae (or $O$. concolor presenting $2 \mathrm{n}=60$ and $\mathrm{AN}=62$ ) in the gallery forests in Cerrado biome from the states of Goiás and Minas Gerais and Distrito Federal (Andrades-Miranda 2001, Andrade \& Bonvicino 2003, Langguth et al. 2005, Vieira \& Palma 2005 and references therein). However we did not examine these specimens and this classification is based only at the karyotypes or the identifications published. No record of Oecomys of any species was found for the Caatinga biome (Freitas et al. 2005, Oliveira et al. 2003).
There is a published record of $O$. catherinae from Pinkaití Research Station, Ourilândia do Norte, in the southeast of the state of Pará, in a region of the Amazon forest consisting of approximately $70 \%$ forest and 30\% Cerrado (Lambert et al. 2006). However these identifications were just hypotheses made by Robert Voss (R. Voss, personal communication). Another possible record of $O$. catherinae in the Amazon biome is from Andrades-Miranda et al. (2001), who found $O$. concolor presenting $2 \mathrm{n}=60, \mathrm{AN}=62$, in Guajará-Mirim, in the state of Rondônia. If confirmed these records show another disjunct population of $O$. catherinae in the north of Brazil and extend the species occurrence to the southern limits of the Amazon forest. Another hypothesis states that more than one species may share the same chromosomal complement, which would make necessary a detailed revision, since we have not observed all specimens or the type of $O$. catherinae.

External and cranial measurements of the individuals from the state of Paraíba and of all examined specimens are shown in Table 2 and 3. No sexual dimorphism was found in cranial measurements

Table 2. External measures (in $\mathrm{mm}$ ) and weight (in $\mathrm{g}$ ) of the collected specimens of Oecomys catherinae in Paraíba State. AC = age class; HBL = Head and Body length; TL = Tail Length; HF = Hindfoot; $\mathrm{E}=$ Ear; $\mathrm{W}=$ weight. 1 = Means of all examined individuals from Atlantic Forest localities; 2 = data from Bonvicino et al. (2008). UFPE = Universidade Federal de Pernambuco.

Tabela 2. Medidas externas (em mm) e massa corporal (em g) dos espécimens de Oecomys catherinae coletados no estado da Paraíba . Sex = sexo; AC = classe etária; $\mathrm{HBL}=$ comprimento da cabeça e corpo; $\mathrm{TL}=$ comprimento da cauda; $\mathrm{HF}=$ pé; $\mathrm{E}=$ Orelha; $\mathrm{W}=$ peso. $1=\mathrm{Médias}$ de todos os indivíduos analisados coletados na Floresta Atlântica; 2 = dados retirados de Bonvicino et al. (2008). UFPE = Universidade Federal de Pernambuco.

\begin{tabular}{|c|c|c|c|c|c|c|c|}
\hline Museum number & Sex & $\mathbf{A C}$ & HBL (n) & TL (n) & HF (n) & $\mathbf{E}(\mathbf{n})$ & $\mathbf{W}(\mathbf{n})$ \\
\hline UFPE1890 & $\mathrm{m}$ & 2 & 109.00 & 136.00 & 28.50 & 18.50 & 32.00 \\
\hline UFPE1889 & $\mathrm{m}$ & 3 & 138.00 & 147.00 & 27.00 & 19.00 & 67.00 \\
\hline UFPE1896 & $\mathrm{m}$ & 4 & 140.00 & 156.00 & 29.00 & 20.00 & 71.00 \\
\hline UFPE1897 & $\mathrm{f}$ & 4 & 145.00 & 125.00 & 27.00 & 18.00 & 68.00 \\
\hline O. catherinae $^{1}$ & - & - & $136.76(25)$ & $157.28(25)$ & $28.60(25)$ & $18.76(25)$ & $74.45(24)$ \\
\hline O. catherinae ${ }^{2}$ & - & - & $132-150$ & 166.00 & 30.00 & 20.00 & 70.00 \\
\hline
\end{tabular}

Table 3. Descriptive statistics (16 males and 11 females) of Oecomys catherinae specimens examined and results from $t$-test to detect sexual dimorphism. Refer to text for measurement acronyms.

Tabela 3. Estatísticas descritivas dos espécimes de Oecomys catherinae examinados (16 machos e 11 fêmeas) e resultados dos testes- $t$ para detectar dimorfismo sexual. Consultar o texto para o significado dos acrônimos.

\begin{tabular}{|c|c|c|c|c|}
\hline Measurement & $\mathbf{n}$ & Mean ( \pm Std.Dev.) & Range & $t$-test (p) \\
\hline CIL & 27 & $30.72( \pm 1.64)$ & $26.07-35.41$ & 0.379 \\
\hline $\mathrm{BOC}$ & 27 & $7.06( \pm 0.38)$ & $6.4-8.46$ & 0.239 \\
\hline LD & 27 & $8.66( \pm 0.56)$ & $7.06-10.16$ & 0.258 \\
\hline LPB & 27 & $6.96( \pm 0.47)$ & $6.08-8.46$ & 0.845 \\
\hline LIF & 27 & $5.84( \pm 0.38)$ & $5.16-6.86$ & 0.269 \\
\hline $\mathrm{BIF}$ & 27 & $2.41( \pm 0.16)$ & $2.16-2.81$ & 0.275 \\
\hline LM & 27 & $5.17( \pm 0.38)$ & $4.73-6.92$ & 0.329 \\
\hline BM1 & 27 & $1.44( \pm 0.11)$ & $1.29-1.87$ & 0.447 \\
\hline M1M1 & 27 & $6.19( \pm 0.37)$ & $5.56-7.73$ & 0.556 \\
\hline $\mathrm{BL}$ & 26 & $3.67( \pm 0.38)$ & $2.83-4.74$ & 0.771 \\
\hline $\mathrm{HS}$ & 27 & $9.7( \pm 0.49)$ & $8.97-11.36$ & 0.180 \\
\hline LR & 26 & $11.93( \pm 0.79)$ & $10.16-13.82$ & 0.753 \\
\hline RW & 27 & $6.35( \pm 0.47)$ & $5.48-7.54$ & 0.275 \\
\hline LIB & 27 & $6.03( \pm 0.37)$ & $5.22-6.8$ & 0.295 \\
\hline IOL & 27 & $11.77( \pm 0.49)$ & $10.16-12.81$ & 0.256 \\
\hline $\mathrm{ZB}$ & 27 & $17.52( \pm 1.04)$ & $14.3-20.07$ & 0.234 \\
\hline $\mathrm{BB}$ & 27 & $13.95( \pm 0.63)$ & 13-16.01 & 0.661 \\
\hline $\mathrm{BZP}$ & 27 & $3.96( \pm 0.27)$ & $3.27-4.33$ & 0.677 \\
\hline $\mathrm{MH}$ & 25 & $8.84( \pm 0.58)$ & $7.79-10.39$ & 0.695 \\
\hline $\mathrm{ML}$ & 27 & $16.94( \pm 0.91)$ & $14.68-19.53$ & 0.639 \\
\hline
\end{tabular}


Asfora, P.H. et al.

(Table 2) and the only external measurement differing between the sexes was "Ear Length" with a $\mathrm{p}=0.024$. Based on their work with O. sydandersoni in Bolivia, Carleton et al. (2009) state that none of the 18 craniodental variables demonstrated significant secondary sexual dimorphism.

The karyotype of the specimens from the state of Paraiba showed a $2 \mathrm{n}=60$ and an $\mathrm{AN}=62$ (Figure 4b), matching the already described karyotype for the species (Langguth et al. 2005). Nine karyotyped individuals, from a total of 14, recorded in Cachoeiras de Macacu, Guapimirim and Sumidouro in the Atlantic Forest of Rio de Janeiro state, presented a polymorphism in the autosomal number, with AN = 64 (Table 4). These individuals presented the autosomal complement composed by one pair of large subtelocentric chromosomes, two pairs of small metacentric chromosomes and 26 pairs of large to small acrocentric chromosomes (Figure 4a). The difference between this latter karyotype and the $2 n=60, A N=62$,
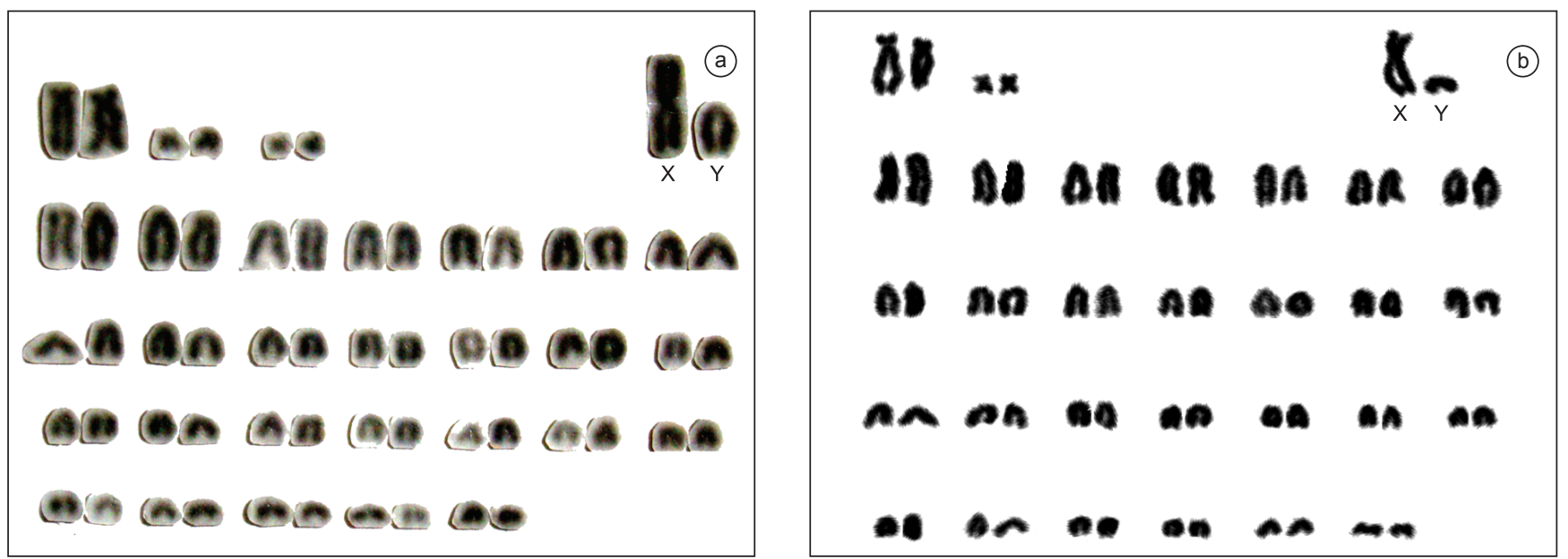

Figure 4. (a) Karyotype of Oecomys catherinae (SU86) collected in Sumidouro, Rio de Janeiro State, 2n =60, AN = 64 and (b) karyotype of Oecomys catherinae (UFPE1889) collected in Mamanguape, Paraíba State, $2 \mathrm{n}=60, \mathrm{AN}=62$ with conventional staining.

Figura 4. (a) Cariótipo de Oecomys catherinae (SU86) coletado em Sumidouro, Rio de Janeiro, $2 \mathrm{n}=60$, AN = 64 (a) e (b) cariótipo de Oecomys catherinae (UFPE1889) coletado em Mamanguape, Paraíba, $2 \mathrm{n}=60, \mathrm{AN}=62$ (b), observados em coloração convencional.

Table 4. Recorded karyotypes of Oecomys catherinae in literature. Brazilian states: $\mathrm{GO}=$ Goiás, $\mathrm{PB}=\mathrm{Paraíba}$, $\mathrm{PE}=\mathrm{Pernambuco}$, RJ $=\mathrm{Rio}$ de Janeiro, $\mathrm{SP}=$ São Paulo. $2 \mathrm{n}=$ diploid number, $\mathrm{AN}=$ autossomal number. 1 = this study, 2 = Andrade and Bonvicino (2003), 3 = Andrades-Miranda et al. (2001), 4 = Langguth et al. (2005); 5 = Pinheiro \& Geise (2008). See appendix for more details about the localities.

Tabela 4. Cariótipos registrados para Oecomys catherinae. Estados brasileiros: GO = Goiás, PB = Paraíba, PE = Pernambuco, RJ = Rio de Janeiro, $\mathrm{SP}=$ São Paulo. $2 \mathrm{n}$ = número diplóide; $\mathrm{AN}$ = número autossômico. 1 = este estudo; 2 = Andrade e Bonvicino (2003); 3 = Andrades-Miranda et al. (2001); 4 = Langguth et al. (2005); 5 = Pinheiro \& Geise (2008). Ver apêndice para maiores detalhes sobre as localidades.

\begin{tabular}{|c|c|c|c|c|}
\hline City & UF & $2 n$ & $\mathbf{A N}$ & Source \\
\hline Caldas Novas & $\mathrm{GO}$ & 60 & 62 & 3 \\
\hline Minaçu & $\mathrm{GO}$ & 60 & 62 & 3 \\
\hline Teresina de Goiás & GO & 60 & 62 & 2 \\
\hline Mamanguape & PB & 60 & 62 & 1 \\
\hline Cruz do Espírito Santo & $\mathrm{PB}$ & 60 & 62 & 1 \\
\hline Igarassú & PE & 60 & 62 & 1 \\
\hline Jaqueira & PE & 60 & 62 & 1 \\
\hline Paudalho & $\mathrm{PE}$ & 60 & 62 & 1 \\
\hline Rio Formoso & $\mathrm{PE}$ & 60 & 62 & 4 \\
\hline São Lourenço da Mata & $\mathrm{PE}$ & 60 & 62 & 4 \\
\hline Cachoeiras de Macacu & RJ & 60 & $62 / 64$ & 1 \\
\hline Cambuci & RJ & 60 & 62 & 1 \\
\hline Casimiro de Abreu & $\mathrm{RJ}$ & 60 & 62 & 1 \\
\hline Guapimirim & RJ & 60 & 62 & 2 \\
\hline Guapimirim & RJ & 60 & 64 & 1 \\
\hline Sumidouro & $\mathrm{RJ}$ & 60 & 62 & 2 \\
\hline Sumidouro & $\mathrm{RJ}$ & 60 & 64 & 1 \\
\hline Capão Bonito & SP & 60 & 62 & 2 \\
\hline Ubatuba & SP & 60 & $62 / 64$ & 5 \\
\hline
\end{tabular}


is the presence of a third small metacentric pair (Figure 4a). Pinheiro \& Geise (2008) also reported the karyotype $2 n=60$ and $A N=64$ from Picinguaba, Ubatuba, in the state of São Paulo. We re-analyzed these karyotypes from Pinheiro \& Geise (2008) and confirmed that they showed the same polymorphism as the individuals from the state of Rio de Janeiro.

These data suggest that this polymorphism could be shared by the populations occurring from Cachoeiras de Macacu and Sumidouro, in the state of Rio de Janeiro, to Ubatuba, in the state of São Paulo, inherited from a common ancestor. And it probably could also occur in individuals of $O$. catherinae collected in the intermediary area of Itatiaia and Mangaratiba, in the state of Rio de Janeiro, (Figure 4a).

Our work confirms the lack of information about the taxonomic status and geographic distribution of the Oecomys catherinae. We found many uncertain records based mainly in old data of $O$. concolor, $O$. aff. concolor or $O$. group concolor. It shows an urgent need for a taxonomic revision to confirm the identity of these individuals. We showed three apparently disjunctive populations of O. catherinae in: a) the Northern, b) Northeastern and c) Central and Southeastern regions of Brazil, and a chromosomal polymorphism shared by the meta-populations spread among the states of Rio de Janeiro and São Paulo. These data could be a sampling artifact, or O. catherinae as currently recognized could be composed by more than one species.

\section{Acknowledgements}

Financial support was provided by CNPq (Proc 480877/2007-6 and 553875/2006-0) and FACEPE (APQ-0351-2.04/06). PHA is supported by a fellowship from FAPERJ, LG received research grants from UERJ (Prociencia), CNPq, and CAPES. We thank Mr. Ivaldo Marques for logistic support, the Reserva Biológica Guaribas team for the field assistance, and the Usina São João owners for granting us permission to work there. We are also thankful to the students of the Reserva Biológica Guaribas First Small Mammals Field Course and A.L.C.P. Nascimento, C.E.C. Anacleto, J.A.F. Silva, A.P.A. Júnior and A. B. Sousa for helping with the fieldwork. J. Bloch made the final English revision, and two anonymous reviewers made several suggestions that improved the text.

\section{References}

ANDRADE, A.F. \& BONVICINO, C.R. 2003. A new karyological variant of Oecomys (Rodentia: Sigmodontinae) and its phylogenetic relationship based on molecular data. Genome 46:195-203. PMid:12723035. http:// dx.doi.org/10.1139/g02-123

ANDRADES-MIRANDA, J., OLIVEIRA, L.F.B., ZANCHIN, N.I.T. \& MATTEVI, M.S. 2001. Chromosomal description of the rodent genera Oecomys and Nectomys from Brazil. Acta Theriol. 46:269-278. http:// dx.doi.org/10.1007/BF03192433

ASFORA, P.H. \& PONTES, A.R.M, M.S. 2009. The small mammals of the highly impacted North-eastern Atlantic Forest of Brazil, Pernambuco Endemism Center. Biota Neotrop. 9(1):031-035. ISSN 1676-0603. http:// www.biotaneotropica.org.br/v8n4/en/abstract?article+bn00409012009

BONVICINO, C. R., OLIVEIRA, J.A. \& D'ANDREA, P.S. 2008. Guia dos Roedores do Brasil, com chaves para gêneros baseadas em caracteres externos. Centro Pan-Americano de Febre Aftosa - OPAS/OMS, Rio de Janeiro.

CACERES, N., CARMignotTO, A.P., FISCHER, E. \& SANTOS, C.F. 2008. Mammals from Mato Grosso do Sul, Brazil. Check List 4(3):321-335.
CARLETON, M.D., EMMONS, L.H. \& MUSSER, G.C. 2009. A New Species of the Rodent Genus Oecomys (Cricetidae: Sigmodontinae: Oryzomyini) from Eastern Bolivia, with Emended Definitions of $O$. concolor (Wagner) and O. mamorae (Thomas). Am. Mus. (3661):1-32. http://dx.doi.org/10.1206/612.1

CERQUEIRA, R., VIEIRA, M.V. \& SALLES, L.O. 1989. Habitat and reproduction of Rhipidomys cearanus at São Benedito, Ceará (Rodentia, Cricetidae). Cienc. Cult. 41(10):1009-1013.

CHEREM, J.J., SIMÕES-LOPES, P.C., ALTHOFF, S. \& GRAIPEL, M.E. 2004. Lista dos mamíferos do Estado de Santa Catarina, Sul Do Brasil. Mastozool. Neotrop. 11(2):151-184.

COSTA, L., BONVICINO, C., WEKSLER, M. \& PAGLIA, A. 2008. Oecomys catherinae. In IUCN Red List of Threatened Species. (International Union for Conservation of Nature-IUCN). Version 2010.2. www.iucnredlist.org (último acesso em 15/08/2010).

FREITAS, R.R., ROCHA, P.L.B. \& SIMÕES-LOPES, P.C. 2005. Habitat structure and small mammals abundances in one semiarid landscape in the Brazilian Caatinga. Rev. Bras. Zool. 22(1):119-129. http://dx.doi. org/10.1590/S0101-81752005000100015

GEISE, L., BERGALlO, H.G., ESBERARD, C.E.L., ROCHA, C.F.D. \& SLUYS, M.V. 2008. The karyotype of Blarinomys breviceps (Mammalia: Rodentia: Cricetidae) with comments on its morphology and some ecological notes. Zootaxa (Online) 1907:47-60.

HERSHKOVITZ, P. 1960. Mammals of Northern Colombia, Preliminary no.8: arboreal rice rats, a systematic revision of the subgenus Oecomys, genus Oryzomys. Proc. U.S. Nat. Mus. 110:535-539.

HIJMANS, R.J., CAMERON, S.E., PARRA, J.L., JONES, P.G. \& JARVIS, A. 2005. Very high resolution interpolated climate surfaces for global land areas. Int. J. Climatol. 25:1965-1978. http://dx.doi.org/10.1002/joc.1276

INSTITUTO BRASILEIRO DE GEOGRAFIA E ESTATÍSTICA - IBGE. 1993. Mapa de Vegetação do Brasil. IBGE, Brasília.

INSTITUTO NACIONAL DE PESQUISAS ESPACIAIS - INPE. Centro de Previsões de Tempo e Estudos Climáticos - CPTEC. 2009. Proclima: Programa de monitoramento climático em tempo real da região Nordeste. Balanço hídrico - gráficos/tabela.

LAMBERT, T.D., MALCOLM, J.R. \& ZIMMERMAN, B.L. 2006. Amazonian small mammal abundances in relation to habitat structure and resource abundance. J. Mammal. 87(4):766-776. http://dx.doi. org/10.1644/05-MAMM-A-261R1.1

LANGGUTH, A., MAIA, V. \& MATTEVI, M.S. 2005. Karyology of large size Brazilian species of the genus Oecomys Thomas, 1906 (Rodentia, Muridae, Sigmodontinae). Arq. Mus. Nac. 63(1):183-190.

MUSSER, G.G. \& CARLETON, M.D. 2005. Superfamily Muroidea, Family Cricetidae, Subfamily Sigmodontinae. In Mammal Species of the World (D.E. Wilson \& D.M. Reeder, eds). Johns Hopkins University Press, Baltiomre, p. 1086-1186.

NATIONAL OCEANIC AND ATMOSPHERIC ADMINISTRATION NOAA \& NATIONAL GEOPHYSICAL DATA CENTER - NGDC. 2001. 2-minute Gridded Global Relief Data (ETOPO2). NGDC, Boulde. http://www.ngdc.noaa.gov/mgg/fliers/06mgg01.html (último acesso em 19/04/2010).

OLIVEIRA, F.F. \& LANGGUTH, A. 2004. Pequenos mamíferos (Didelphimorphia e Rodentia) de Paraíba e Pernambuco. Rev. Nordest. Biol. 18:19-86.

OLIVEIRA, J.A., P.R. GONÇALVES \& C.R. BONVICINO. 2003. Mamíferos da Caatinga. In Ecologia e conservação da Caatinga (I.R. Leal, M. Tabarelli \& J.M.C. Silva, eds). Editora Universitária da Universidade Federal de Pernambuco, Recife, p. 275-333.. 
Asfora, P.H. et al.

OLSON, D.M., DINNERSTEIN, E., WIKRAMANAYAKE, D.E., BURGESS, N.D., POWELL, G.V.N., UNDERWOOD, E.C., D'AMICO, J.A., LOUCKS, C.J., RICKETTS, T.H., KURA, Y., LAMOREUX, J.F., WETTENGEL, W.W., HEDAO, P. \& KASEEEM, K.R. 2001. Terrestrial ecoregions of the world: A new map of life on Earth. BioScience 51:933-938. http://dx.doi.org/10.1641/00063568(2001)051[0933:TEOTWA]2.0.CO;2

PARDINI, R. 2004. Effects of forest fragmentation on small mammals in an Atlantic Forest landscape. Biodivers. Conserv. 13:2567-2586. http:// dx.doi.org/10.1023/B:BIOC.0000048452.18878.2d

PERCEQUILLO, A.R., WEKSLER, M. \& COSTA, L.P. 2011. A new genus and species of rodent from the Brazilian Atlantic Forest (Rodentia: Cricetidae: Sigmodontinae: Oryzomyini), with comments on oryzomyine biogeography. Zool. J. Linn. Soc-Lond. 161:357-390.

PINHEIRO, P.S. \& GEISE, L. 2008. Non-volant mammals of Picinguaba, Ubatuba, state of São Paulo, southeastern Brazil. Bol. Mus. Biol. Mello Leitão 23:51-59.

PINTO, I.S., BOTELHO, J.R., LEONORA, L.P., LEITE, Y.L.R. \&. LINARDI, P.M. 2009a. Siphonaptera Associated with Wild Mammals From the Central Atlantic Forest Biodiversity Corridor in Southeastern Brazil. J. Med. Entomol. 46(5):1146-1151. http://dx.doi.org/10.1603/033.046.0523
PINTO, I.S., LOSS, A.C.C., FALQUETO, A. \& LEITE, Y.L.R. 2009 b. Pequenos mamíferos não voadores em fragmentos de Mata Atlântica e áreas agrícolas em Viana, Espírito Santo, Brasil. Biota Neotrop. 9(3):355360. http://www.biotaneotropica.org.br/v9n3/pt/abstract?inventory+ bn03109032009

RODRIGUES e SILVA, F.B., SANTOS, J.C.P., SOUZA NETO, N.C., SILVA, A.B., RICHÉ, G.R., TONNEAU, J.P., BRITO, L.T.L., CORREIA, R.C., SILVA, F.H.B.B., SILVA, C.P., LEITE, A.P., OLIVEIRA NETO, M.B., PARAHYBA, R.B.V., ARAÚJO FILHO, J.C., CAVALCANTI, A.C., BURGOS, N. \& REIS, R.M.G. 2000. Zoneamento Agroecológico do Nordeste: Diagnóstico e Prognóstico. Embrapa Solos e Embrapa Semi-Árido, Recife.

SOUZA, M.A.N., LANGGUTH, A. \& GIMENEZ, E.A. 2004. Mamíferos dos brejos de altitude da Paraíba e Pernambuco. In Brejos de altitude em Pernambuco e Paraíba: história natural, ecologia e conservação (K.C. Porto, J.J.P. Cabral \& M. Tabarelli, eds.). Ministério do Meio Ambiente, Brasília, p. 229-254.

VIEIRA, E.M. \& PALMA, A.R.T. 2005. Pequenos mamíferos do Cerrado: distribuição dos gêneros e estrutura das comunidades nos diferentes habitats. In Cerrado: Ecologia, biodiversidade e conservação (A. Scariot, J.C. Sousa-Filho \& J.M. Felfili, orgs). Ministério do Meio Ambiente, Brasília, p. 265-282.

Recebido em 03/05/2010

Versão reformulada recebida em 05/02/2011

Publicado em 15/04/2011 


\section{Apendix I e II}

Appendix I. Localities used to compose the map of occurrence of Oecomys catherinae in Brazil: 1 = Carleton et al. (2009), $2=$ Cáceres et al. (2008), $3=$ Pinheiro \& Geise (2008), 4 = Lambert et al. (2006), $5=$ Langguth et al. (2005), $6=$ Andrade \& Bonvicino (2003), $7=$ Pinto et al. (2009a), $8=$ Pinto et al. (2009b), $9=$ Andrades-Miranda et al. (2001), $10=$ Asfora $\&$ Pontes (2009), $11=$ Vieira $\&$ Palma (2005), $12=$ Percequillo et al. $(2011)$, TS $=$ this paper. MN $=$ Museu Nacional, Universidade Federal do Rio de Janeiro.

\begin{tabular}{|c|c|c|c|c|c|}
\hline Number & City & State & Latitude & Longitude & Source \\
\hline 1 & Mamanguape & $\mathrm{PB}$ & $06^{\circ} 48^{\prime} 02^{\prime \prime} \mathrm{S}$ & $35^{\circ} 05^{\prime} 47 \mathrm{~W}$ & TS \\
\hline 2 & Cruz do Espírito Santo & PB & $07^{\circ} 06^{\prime} 55^{\prime \prime} \mathrm{S}$ & $35^{\circ} 04^{\prime} 47^{\prime \prime} \mathrm{W}$ & TS \\
\hline 3 & Ourilândia do Norte & PA & $07^{\circ} 46^{\prime} 14^{\prime \prime} \mathrm{S}$ & $51^{\circ} 57^{\prime} 43^{\prime \prime} \mathrm{W}$ & 4 \\
\hline 4 & Igarassú & PE & $07^{\circ} 50^{\prime} 27^{\prime \prime} \mathrm{S}$ & $35^{\circ} 00^{\prime} 06^{\prime \prime} \mathrm{W}$ & TS \\
\hline 5 & Paudalho & $\mathrm{PE}$ & $07^{\circ} 50^{\prime} 38^{\prime \prime} \mathrm{S}$ & $35^{\circ} 06^{\prime} 07^{\prime \prime} \mathrm{W}$ & TS \\
\hline 6 & São Lourenço da Mata & $\mathrm{PE}$ & $08^{\circ} 00^{\prime} 12^{\prime \prime} \mathrm{S}$ & $35^{\circ} 01^{\prime} 17^{\prime \prime} \mathrm{W}$ & 5 \\
\hline 7 & Jaqueira & $\mathrm{PE}$ & $08^{\circ} 42^{\prime} 59^{\prime \prime} \mathrm{S}$ & $35^{\circ} 50^{\prime} 37^{\prime \prime} \mathrm{W}$ & 10 \\
\hline 8 & Rio Formoso & $\mathrm{PE}$ & $08^{\circ} 43^{\prime} 47^{\prime \prime} \mathrm{S}$ & $35^{\circ} 10^{\prime} 34^{\prime \prime} \mathrm{W}$ & 5 \\
\hline 9 & Ibateguara & $\mathrm{AL}$ & $08^{\circ} 59^{\prime} 42^{\prime \prime} \mathrm{S}$ & $35^{\circ} 50^{\prime} 27^{\prime \prime} \mathrm{W}$ & 10 \\
\hline 10 & Guajará-Mirim & RO & $10^{\circ} 47,27 ” \mathrm{~s}$ & $65^{\circ} 19^{\prime} 55^{\prime \prime} \mathrm{W}$ & 9 \\
\hline 11 & Minaçu & GO & $13^{\circ} 33^{\prime} 49^{\prime \prime} \mathrm{S}$ & $48^{\circ} 13^{\prime} 19^{\prime \prime} \mathrm{W}$ & 9 \\
\hline 12 & Teresina de Goiás & GO & $13^{\circ} 46^{\prime} 35^{\prime \prime} \mathrm{S}$ & $47^{\circ} 15^{\prime} 53^{\prime \prime} \mathrm{W}$ & 6 \\
\hline 13 & Brasília & DF & $15^{\circ} 49^{\prime} 36^{\prime \prime} \mathrm{S}$ & $47^{\circ} 55^{\prime} 18^{\prime \prime} \mathrm{W}$ & 11 \\
\hline 14 & Ipameri & GO & $17^{\circ} 43^{\prime} 29 ” \mathrm{~S}$ & $48^{\circ} 09^{\prime} 35^{\prime \prime} \mathrm{W}$ & 9 \\
\hline 15 & Caldas Novas & GO & $17^{\circ} 44^{\prime} 42^{\prime \prime} \mathrm{S}$ & $48^{\circ} 37^{\prime} 30^{\prime \prime} \mathrm{W}$ & 9 \\
\hline 16 & Corumbaíba & GO & $18^{\circ} 08^{\prime} 35^{\prime \prime} \mathrm{S}$ & $48^{\circ} 33^{\prime} 32^{\prime \prime} \mathrm{W}$ & 9 \\
\hline 17 & Águia Branca & ES & $18^{\circ} 53^{\prime} 23^{\prime \prime} \mathrm{S}$ & $40^{\circ} 49^{\prime} 36^{\prime \prime} \mathrm{W}$ & 7 \\
\hline 18 & Pancas & ES & $19^{\circ} 12^{\prime} 16^{\prime \prime} \mathrm{S}$ & $40^{\circ} 47^{\prime} 43^{\prime \prime} \mathrm{W}$ & 7 \\
\hline 19 & Conceição das Alagoas & MG & $19^{\circ} 54^{\prime} 50^{\prime \prime} \mathrm{S}$ & $48^{\circ} 23^{\prime} 11^{\prime \prime} \mathrm{W}$ & $\mathrm{MN}$ \\
\hline 20 & Santa Teresa & ES & $19^{\circ} 57^{\prime} 10^{\prime \prime} \mathrm{S}$ & $40^{\circ} 31^{\prime} 30^{\prime \prime} \mathrm{W}$ & 7 \\
\hline 21 & Pirapitinga & MG & $20^{\circ} 07^{\prime} 60^{\prime \prime} \mathrm{S}$ & $42^{\circ} 17^{\prime} 60^{\prime \prime} \mathrm{W}$ & TS \\
\hline 22 & Cariacica & ES & $20^{\circ} 16^{\prime} 52 ” \mathrm{~S}$ & $40^{\circ} 31^{\prime} 19^{\prime \prime} \mathrm{W}$ & 7 \\
\hline 23 & Viana & ES & $20^{\circ} 23^{\prime} 20^{\prime \prime} \mathrm{S}$ & $40^{\circ} 27^{\prime} 41^{\prime \prime} \mathrm{W}$ & 8 \\
\hline 24 & Barra Grande & SP & $20^{\circ} 25^{\prime} 00^{\prime \prime} \mathrm{S}$ & $48^{\circ} 50^{\prime} 00^{\prime \prime} \mathrm{W}$ & 5 \\
\hline 25 & Brasilândia & MS & $21^{\circ} 15^{\prime} 00 ” \mathrm{~S}$ & $52^{\circ} 02^{\prime} 00^{\prime \prime} \mathrm{W}$ & 2 \\
\hline 26 & Cambuci & $\mathrm{RJ}$ & $21^{\circ} 29^{\prime} 35^{\prime \prime} \mathrm{S}$ & $41^{\circ} 52^{\prime} 20^{\prime \prime} \mathrm{W}$ & TS \\
\hline 27 & Sumidouro & $\mathrm{RJ}$ & $22^{\circ} 02^{\prime} 42^{\prime \prime} \mathrm{S}$ & $42^{\circ} 40^{\prime} 24^{\prime \prime} \mathrm{W}$ & TS \\
\hline 28 & Itatiaia & RJ & $22^{\circ} 26^{\prime} 14^{\prime \prime} \mathrm{S}$ & $44^{\circ} 36^{\prime} 00^{\prime \prime} \mathrm{W}$ & TS \\
\hline 29 & Casimiro de Abreu & RJ & $22^{\circ} 29^{\prime} 05^{\prime \prime} \mathrm{S}$ & $42^{\circ} 12^{\prime} 04^{\prime \prime} \mathrm{W}$ & TS \\
\hline 30 & Cachoeiras de Macacu & RJ & $22^{\circ} 32^{\prime} 35^{\prime \prime} \mathrm{S}$ & $42^{\circ} 48^{\prime} 19^{\prime \prime} \mathrm{W}$ & TS \\
\hline 31 & Guapimirim & RJ & $22^{\circ} 33^{\prime} 48^{\prime \prime} \mathrm{S}$ & $42^{\circ} 57^{\prime} 53^{\prime \prime} \mathrm{W}$ & TS \\
\hline 32 & Mangaratiba & RJ & $22^{\circ} 55^{\prime} 12.1 ” \mathrm{~S}$ & $44^{\circ} 06^{\prime} 32^{\prime \prime} \mathrm{W}$ & TS \\
\hline 33 & Ubatuba & SP & $23^{\circ} 20^{\prime} 45^{\prime \prime} \mathrm{S}$ & $44^{\circ} 51^{\prime} 00^{\prime \prime} \mathrm{W}$ & 3 \\
\hline 34 & Capão Bonito & SP & $24^{\circ} 00^{\prime} 14^{\prime \prime} \mathrm{S}$ & $48^{\circ} 20^{\prime} 21^{\prime \prime} \mathrm{W}$ & 6 \\
\hline 35 & Sete Barras & SP & $24^{\circ} 14^{\prime} 04^{\prime \prime} \mathrm{S}$ & $48^{\circ} 05^{\prime} 11^{\prime \prime} \mathrm{W}$ & 6 \\
\hline 36 & Parque Estadual Intervales, Ribeirão Grande & SP & $24^{\circ} 20^{\prime} \mathrm{S}$ & $48^{\circ} 25^{\prime} \mathrm{W}$ & 12 \\
\hline 37 & Joinville & $\mathrm{SC}$ & $26^{\circ} 18^{\prime} 16^{\prime \prime} \mathrm{S}$ & $48^{\circ} 50^{\prime} 54^{\prime \prime} \mathrm{W}$ & 1 \\
\hline
\end{tabular}


Asfora, P.H. et al.

Apendix II. Specimens examined: The 52 specimens analyzed by us are deposited in collections from Museu Nacional, Universidade Federal do Rio de Janeiro (MN) and Universidade Federal de Pernambuco (UFPE). Individuals used in cranial analyses are marked with * and individuals kariotyped by us are marked with \#. RB-M, FU, FS and SU = field number of Laboratório de Vertebrados, Universidade Federal do Rio de Janeiro; HGB CFVC = field number of Helena de Godoy Bergallo. ALAGOAS: Ibateguara Loc. 9 (UFPE1666*); MINAS GERAIS: Conceição das Alagoas Loc. 19 (MN68206*), Pirapitinga Loc. 21 (MN72737\#, MN72738\#); PARAÍBA: Cruz do Espírito Santo Loc. 2 (UFPE1896*\#, UFPE1897*\#), Mamanguape Loc. 1 (UFPE1889*\#, UFPE1890\#); PERNAMBUCO: Igarassú Loc. 4 (UFPE1892*\#), Jaqueira Loc. 7 (UFPE1893*, UFPE1894*, UFPE1891*\#), Paudalho Loc. 5 (UFPE1888*\#), Rio Formoso Loc. 8 (UFPB4450); RIO DE JANEIRO: Cachoeiras de Macacu Loc. 30 (MN74364\#, MN74370*\#, MN74374*, MN74371*\#, MN74372*\#, MN74373), Cambuci Loc. 26 (RB-M-3-51\#, RB-M-3-52\#), Casimiro de Abreu Loc. 29 (FU16\#, FU17\#), Guapimirim Loc. 31 (FS04-77, MN74359*\#, FS04-27, MN74360*\#, MN74361, MN74362*, MN74365, MN74366*\#, MN74367\#, MN74363*, MN74368\#, MN74369*\#, FS13-96*), Itatiaia Loc. 28 (HGBCFVC 04), Mangaratiba Loc. 33 (RB-M-58), Sumidouro Loc. 27 (SU63\#, SU86\#); SÃO PAULO: Ubatuba Loc. 34 (MN74376*\#, MN74380*, MN74375*, MN74377*\#, MN74378\#, MN74379\#, MN74381*) 